\title{
HUBUNGAN KESEJAHTERAAN SPIRITUAL DENGAN KUALITAS HIDUP PADA PASIEN KANKER PAYUDARA DI POLI BEDAH RSUP Dr. M. DJAMIL PADANG
}

\author{
Lola Despitasari, Lenni Sastra, Fitria Alisa, Letivia Azro \\ Prodi S1 Keperawatan, STIKes MERCUBAKTIJAYA Padang \\ Email: Ioladespitasari1986@gmail.com
}

\begin{abstract}
ABSTRAK
Di Indonesia peningkatan jumlah kasus baru serta jumlah kematian akibat kanker payudara terus meningkat. Situasi yang dialami pasien kanker payudara menyebabkan permasalahan meliputi perubahan secara fisik, fungsi sosial, psikis maupun spiritual seseorang dan ini mempengaruhi kualitas hidup pasien kanker payudara. Salah satu faktor yang mempengaruhi kualitas hidup pasien kanker payudara adalah kesejahteraan spiritual. Tujuan penelitian untuk mengetahui hubungan kesejahteraan spiritual dengan kualitas hidup pada pasien kanker payudara di Poli Bedah RSUP Dr. M. Djamil Padang. Jenis penelitian analitik dengan desain cross sectional. Populasi pada semua wanita penderita kanker payudara yang datang kepoli bedah RSUP Dr.M.Djamil Padang sebanyak509 orang dengan jumlah sampel sebanyak 83 orang. Teknik pengambilan sampel dengan accidental sampling. Data di analisa menggunakan uji Chi square. Hasil penelitian 44,6\% pasien kanker payudara memiliki kualitas hidup buruk, 53\% memiliki kesejahteraan spiritual yang buruk. Hasil uji statistik didapatkan $p$ value $0,000(p \leq 0,05)$, terdapat hubungan antara kesejahteraan spiritual dengan kualitas hidup pada pasien kanker payudara di Poli Bedah RSUP Dr.M.Djamil Padang. Disimpulkan bahwa pasien kanker payudara dengan kesejahteraan spiritual buruk cenderung memiliki kualitas hidup buruk. Diharapkan kepada tenaga kesehatan melakukan penyuluhan dan informasi yang edukatif tentang kualitas hidup kanker payudara sehingga meningkatkan kesejahteraan spiritual.
\end{abstract}

Kata kunci : kanker payudara; kualitas hidup;kesejahteraan spiritual

\section{THE RELATIONSHIP OF SPIRITUAL WELFARE WITH QUALITY OF LIFE IN BREAST CANCER PATIENTS IN SURGERYPOLYCLINIC AT Dr. M. DJAMIL PROVINCIAL GENERAL HOSPITAL OF PADANG}

\begin{abstract}
In Indonesia the increase of new cases and the number of deaths from breast cancer continues to increase. The situation experienced by breast cancer patients cause problems include physical changes, social functions, psychic and spiritual ofsomeone. One of the factors that affect the quality of life of breast cancer patients is spiritual welfare. The purpose of this study was to determine the relationship of spiritual welfare with quality of life in breast cancer patients in Surgery Policlinic at Dr. M. Djamil Provincial General Hospital of Padang. The type of research used was analytic survey, cross sectional study design. The population in this study were all women with breast cancer who came through surgery polyclinic at Dr. M. Djamil Provincial General Hospital of Padang as many as 509 people with samples were 83 people taken by accidental sampling technique. Univaria data were analyzedusing frequency table and bivariate used Chi square. The results showed almost half $44.6 \%$, of breast cancer patients had poor quality of life, more than half53\%, had poor spiritual welfare. Statistical test results obtained $p$ value $0,000(p \leq 0.05)$ means there is a relationship between spiritual welfare with quality of life in breast cancer patients atsurgery polyclinic at Dr. M. Djamil Provincial General Hospital of Padang. The results of this study can be concluded that breast cancer patients with poor spiritual welfare have poor quality of life, while breast cancer patients with spiritual well-being have good quality of life.
\end{abstract}

Keywords : breast cance; quality of life; spiritual welfare 


\section{LATAR BELAKANG}

Kanker payudara merupakan suatu kondisi dimana sel telah kehilangan pengendalian dan mekanisme normalnya, sehingga terjadi pertumbuhan yang tidak normal, cepat dan tidak terkendali yang terjadi pada jaringan payudara (Mulyani dan Nuryani, 2013). Menurut data dari Globocan, International Agency for Research on Cancer (IARC) tahun 2012 diketahui bahwa kanker payudara merupakan penyakit kanker dengan persentase kasus baru tertinggi yaitu sebesar 43,3\% dan persentase kematian akibat kanker payudara sebesar 12,9\%. Secara nasional prevalensi penyakit kanker pada penduduk semua umur di Indonesia tahun 2013 sebesar 1,4\% atau diperkirakan sekitar 347.792 orang. Di Indonesia peningkatan jumlah kasus baru serta jumlah kematian akibat kanker payudara juga terus meningkat dari tahun 2010 sampai 2013 (Infodatin, 2013).

Kanker payudara adalah sebuah tumor ganas yang tumbuh dalam jaringan payudara. Permasalahan yang dialami pada penderita kanker payudara meliputi perubahan secara fisik, fungsi sosial, psikis maupun spiritual seseorang (Prastiwi, 2012). Perubahan fisik yang dialami penderita kanker adalah nyeri, lelah, mual, kerontokan rambut, hilang nafsu makan, perubahan fungsi yang membuat mobilitas terganggu. Perubahan fungsi sosial meliputi hubungan dengan kelompok masyarakat yang kurang. Pada spiritual meliputi keraguan atas keyakinan mereka sendiri, rasa bersalah, konflik bathin antara menerima dan menolak kenyataan penyakit (Ratna, 2010). Masalah yang di alami individu pada perubahan psikis meliputi kecemasan, rasa malu, harga diri menurun, stress dan marah (Oetami dkk, 2014). Perubahan psikis individu juga mencakup kesedihan, kekhawatiran, ketakutan akan masa depan dan kematian yang dimana mempengaruhi kualitas hidup penderitanya. Pengaruh kejiwaan yang kuat akibat kanker payudara dapat berdampak negatif pada kehidupan penderita (Prastiwi, 2012).

Kualitas hidup yang positif ditentukan dari seseorang yang memiliki pandangan psikologis yang positif, memiliki kesejahteraan emosional, memiliki kesehatan fisik dan mental yang baik, memiliki kemampuan fisik untuk melakukan hal- hal yang ingin dilakukan, memiliki hubungan yang baik dengan teman dan keluarga, serta berpatisipasi dalam kegiatan sosial dan rekreasi. Penderita kanker memiliki kualitas hidup yang positif dalam hidupnya maka sikap yang akan ditunjukkan oleh penderita adalah sikap-sikap positif (Prastiwi, 2012). Kualitas hidup yang negatif dapat menimbulkan tingkat isolasi sosial yang tinggi, distress emosional, rendahnya fungsi fisik, ketidakmampuan melakukan kegiatan (Pradana, Putu; Siluh: Surasta, 2012). Menurut Medical News Today (2016) mengatakan bahwa tingkat isolasi sosial dapat meningkatkan resiko kematian penderita kanker sebanyak $29 \%$ dan kondisi pasien yang hidup seorang diri resikonya mencapai $32 \%$.

Penurunan kualitas hidup penderita kanker menurut Clinch dan Schipper dapat dipengaruhi oleh faktor kondisi fisik, kemampuan fungsional, kesejahteraan keluarga, kesejahteraan emosi, spiritual yang dimana kesejahteraan spiritual juga berpengaruh terhadap kualitas hidup seorang penderita kanker (Frisch et al dalam Prastiwi, 2012), fungsi sosial yang diberikan berupa dukungan sosial, kepuasan pada layanan terapi, orientasi masa depan, seksualitas dan fungsi okupasi (Seto, 2010). Berdasarkan penelitian yang dilakukan oleh Prastiwi (2012) dimensi yang mempengaruhi pembentukan kualitas hidup penderita kanker adalah dimensi psikologis yang meliputi spiritualitas, dukungan sosial dan kesejahteraan. Kesejahteraan spiritual merupakan bagian dari aspek spiritual (Monod, 2011).

Berdasarkan survey awal yang dilakukan dengan wawancara kepada 10 orang yang menderita kanker payudara yang datang ke poliklinik bedah RSUP DR.M.Djamil Padang dari 10 penderita kanker payudara yang di wawancara di dapatkan $60 \%$ orang penderita kanker payudara, mereka mengatakan bahwa mereka sering merasa cemas, kelelahan, nyeri dan khawatir dengan penyakitnya, sering merasa keterbatasan saat melakukan pekerjaan, sering merasa malu dengan perubahan pada payudaranya, kehidupan keluarganya sering terganggu karena kondisi fisik dan mereka juga mengatakan bahwa aktivitas sosialnya jadi sering terganggu karena kondisi penyakitnya yang memburuk, $30 \%$ orang penderita kanker 
payudara yang datang ke rumah sakit mengatakan bahwa mereka jarang merasakan kasih sayang dari orang lain, kadang-kadang memiliki hubungan yang baik dengan lingkungan, kadang-kadang mudah tersinggung, kadangkadang sulit melakukan kegiatan yang beratberat dan mereka mengatakan bahwa penyakitnya adalah ujian dan cobaan dari Allah SWTdan10\% orang yang menderita kanker payudara mengatakan bahwa aktivitas sosial nya tidak terganggu karena kondisi penyakitnya masih berada pada stadium I, penderita memiliki hubungan yang baik dengan lingkungan terdekatnya, sering mendapatkan kasih sayang dari orang terdekat dan pada saat terasa adanya benjolan pada payudaranya, penderita segera memeriksakan ke rumah sakit dan meminta pengobatan.Tujuan dari penelitian ini untuk mengetahui hubungan kesejahteraan spiritual dengan kualitas hidup pada pasien kanker payudara di poli bedah RSUP Dr. M.Djamil Padang.

\section{METODE}

Jenis penelitian yang digunakan adalah survey analitik, yaitu untuk melihat kejadian yang diteliti (Nursalam, 2013). Desain penelitan yang digunakan adalah desain penelitian cross sectional, dimana variabel independen dan dependen dikumpulkan dalam waktu yang bersamaan, peneliti ingin mengetahui hubungan antara kesejahteraan spiritual dengan kualitas hidup pada pasien kanker payudara di poli bedah RSUP Dr.M.Djamil Padang. Tempat penelitian adalah di poli bedah RSUP Dr.M.Djamil Padang. Pengumpulan data telah dilaksanakan selama 1 minggu pada tanggal 22-31 Mei 2017.Populasi pada penelitian ini adalah semua wanita penderita kanker payudara yang datang kepoli bedah RSUP Dr.M.Djamil Padang dari bulan Oktober-Desember 2015 sebanyak 509 orang.Sampel penelitian ini berjumlah 83 yaitu pasien kanker payudara yang datang ke poliklinik bedah RSUP Dr. M. Djamil Padang dengan menggunakan teknik accidental sampling pengumpulan data menggunakan kuesioner EORTC qlq c-30 oleh Fayers (2001) terdiri dari 30 pertanyaan dan data kesejahteraan spiritual diperoleh menggunakan kuesioner Spiritual Well
Being Questionaire oleh Fisher (2012) terdiri dari 20 pertanyaan dan data di analisa dengan menggunakan uji Chi square.

HASIL

Kualitas hidup pada pasien kanker payudara

Tabel 1. Distribusi frekuensi kualitas hidup pada pasien kanker payudara

\begin{tabular}{llc}
\hline Kualitas & $(\mathrm{f})$ & $(\%)$ \\
Hidup & 37 & $44,6 \%$ \\
\hline Buruk & 28 & $33,7 \%$ \\
Sedang & 18 & $21,7 \%$ \\
Baik & 83 & $100 \%$ \\
\hline Jumlah & \\
\hline
\end{tabular}

Berdasarkan tabel 1 diatas dapat dilihat bahwa hampir separoh $(44,6 \%)$ pasien kanker payudara di Poli Bedah RSUP Dr.M.Djamil Padang memiliki kualitas hidup buruk.

\section{Kesejahteraan spiritual pada pasien kanker payudara}

Tabel 2. Distribusi frekuensi kesejahteraan spiritual pada pasien kanker payudara

\begin{tabular}{lcc}
\hline $\begin{array}{l}\text { Kesejahteraan } \\
\text { Spiritual }\end{array}$ & $(\mathrm{f})$ & $(\%)$ \\
\hline Buruk & 44 & $53 \%$ \\
Baik & 39 & $47 \%$ \\
\hline Jumlah & 83 & $100 \%$ \\
\hline
\end{tabular}

Berdasarkan tabel 2 diatas dapat dilihat bahwa lebih dari separoh (53\%) pasien kanker payudara di Poli Bedah RSUP Dr. M. Djamil Padang memiliki kesejahteraan spiritual yang buruk.

\section{Hubungan Kesejahteraan Spiritual dengan kualitas hidup pasien kanker payudara}

Tabel 3. Hubungan kesejahteraan spiritual dengan kualitas hidup pada pasien kanker payudara

\begin{tabular}{lcccccccc}
\hline \multirow{2}{*}{$\begin{array}{l}\text { Kesejahteraan } \\
\text { Spiritual }\end{array}$} & \multicolumn{6}{c}{ Kualitas Hidup } \\
\cline { 2 - 7 } & \multicolumn{2}{c}{ Buruk } & \multicolumn{2}{c}{ Sedang } & \multicolumn{2}{c}{ Baik } & Total & P \\
\cline { 2 - 7 } & $\mathrm{f}$ & $\%$ & $\mathrm{f}$ & $\%$ & $\mathrm{~F}$ & $\%$ & & value \\
\hline Buruk & 31 & 70,5 & 1 & 27 & 1 & 2 & 100 & \multirow{2}{*}{0,000} \\
Baik & 6 & 15,4 & 1 & 41 & 1 & 4 & 100 & \\
\hline
\end{tabular}


Berdasarkan table 3 dapat dilihat bahwa proporsi pasien kanker payudara dengan kualitas hidup yang buruk yang memiliki kesejahteraan spiritual yang buruk (70,5\%) dibandingkan dengan pasien kanker payudara yang memiliki kesejahteraan spiritual yang baik (15,4\%). Setelah dilakukan uji statistic Chi-Square didapatkan hasil bahwa $p$ value $0,000(p \leq 0,05)$ artinya terdapat hubungan antara kesejahteraan spiritual dengan kualitas hidup pada pasien kanker payudara di Poli Bedah RSUP Dr.M.Djamil Padang.

\section{PEMBAHASAN}

\section{Kualitas hidup pada pasien kanker payudara}

Berdasarkan hasil penelitian didapatkan bahwa hampir separoh $(44,6 \%)$ pasien kanker payudara di Poli Bedah RSUP Dr.M.Djamil Padang memiliki kualitas hidup buruk. Hasil penelitian ini sama dengan penelitian yang dilakukan oleh Endiyono dan Herdiana (2016) didapatkan bahwa kualitas hidup pasien kanker payudara di RSUD Prof.Dr.Margono Soekarjo Purwokerto mayoritas memiliki kualitas hidup yang cukup sebesar $54,8 \%$. Hal ini sejalan dengan penelitian yang dilakukan oleh Husni, Romadoni, dan Rukiyati (2012) mengungkapkan bahwa sebanyak 53,1\% yang menjalani rawat inap di RSUP Dr. Mohammad Husein Palembang memiliki kualitas hidup yang kurang baik.

Callys-Tagoe, et al (2017) juga mengungkapkan Individu yang didiagnosis kanker payudara akan mengalami beberapa gangguan psikologis, termasuk kecemasan dan depresi. Penelitian juga menunjukkan bahwa individu yang menderita kanker payudara lebih beresiko mengalami kecemasan yang parah, depresi, dan gangguan mood (Srlvastava, et al, 2016). Individu yang menderita kanker payudara pada umumnya akan mengalami kecemasan dan depresi pada setiap tahap, dimulai dari pradiagnosis hingga fase terminal (Srlvastava, et al, 2016).

Kanker payudara terjadi karena adanya kerusakan pada gen yang mengatur pertumbuhan dan diferensiasi sehingga sel itu tumbuh dan berkembang tanpa bisa dikendalikan (Subagja, 2014). Berdasarkan hasil penelitian pada pasien kanker payudara yang mengalami kualitas hidup buruk terlihat pada pasien kanker payudara yang merasa dirinya tidak mampu melakukan kegiatan, depresi, khawatir karena rendahnya fungsi fisik yang membuat pasien menjadi tidak mampu untuk beraktivitas sehingga aktivitas sosial dengan masyarakat dan orang terdekat menjadi terganggu, adanya kesulitan keuangan karena faktor ekonomi pasien dan adanya penyakit kanker payudara yang diderita dikarenakan oleh stadiumnya yang sudah lanjut sehingga menimbulkan repon negatif yang ada pada diri pasien kanker payudara yang dapat membuat kualitas hidupnya menjadi buruk karena dirinya tidak berdaya lagi.

Hal ini juga dapat dilihat dari pengisian kuesioner yang tertinggi pada saat pengumpulan data pasien kanker payudara yang mengalami kualitas hidup buruk yaitu ada (73,5\%) merasa mengalami kesulitan saat melakukan kegiatan yang berat, $(77,1 \%)$ merasa mengalami kesulitan saat melakukan kegiatan santai atau kegiatan hobi yang dilakukan $(72,3 \%)$ mengalami kesulitan tidur, $(78,3 \%)$ mengalami kehilangan nafsu makan, (67,5\%) aktivitas sosial sering terganggu oleh kondisi fisik atau terapi medis yang dijalani oleh pasien kanker payudara, (73,5\%) pasien kanker payudara mengalami kesulitan keuangan akibat kondisi fisik atau terapi medis yang dijalani.

Hasil penelitian berdasarkan umur didapatkan pasien yang mengidap kanker payudara lebih banyak ditemukan pada usia dewasa akhir $(42,2 \%)$. Hasil penelitian ini sejalan dengan penelitian yang dilakukan oleh Kanthi (2014) menyebutkan bahwa responden yang berusia lebih tua cenderung memiliki kualitas hidup yang lebih rendah karena kondisi fisik yang mulai menurun dibandingkan yang berusia muda. Menurut Guner (2006) di dalam Afrimelya (2016) bahwa perbedaan usia pada setiap penderita kanker payudara memberikan dampak terhadap kualitas hidup dikarenakan perbedaan pandangan terhadap penyakit kanker yang dideritanya.

\section{Kesejahteraan spiritual pada pasien kanker payudara}

Berdasarkan hasil penelitian didapatkan bahwa lebih dari separoh (53\%) pasien kanker payudara di Poli Bedah RSUP Dr.M. Djamil Padang memiliki kesejahteraan spiritual yang buruk. Hasil 
penelitian ini hampir sama dengan penelitian yang dilakukan oleh Hasnani (2012) menunjukkan bahwa $(55,4 \%)$ penderita kanker mengalami spiritualitas yang kurang dan hal ini sejalan dengan penelitian Patricia et al (2014) menunjukkan bahwa (44\%) penderita kanker memiliki kesejahteraan spiritual yang kurang baik.

Menurut penelitian Patricia (2014) kesehatan spiritual buruk seperti pasien tidak percaya bisa sembuh dari penyakitnya, pasien merasa dirinya tidak berguna dan merasa tidak ada artinya untuk hidup. Menurut (Pratiwi (2007) di dalam Putri (2016) yaitu seseorang yang tidak mampu dalam membangun spiritualnya menjadi penuh dengan potensi dan tidak ada kemampuan untuk mengetahui tujuan dasar hidupnya, tidak ada cinta, kasih sayang, kedamaian, bahkan tidak ada niat untuk menolong diri sendiri dan orang lain. Menurut Vihena et al (2014) kurangnya dukungan lingkungan pada pasien kronis dapat meningkatkan stres. Dukungan lingkungan yang baik berhubungan dengan kesehatan fisik, mental serta kesejahteraan spiritual yang lebih baik. Menurut Josephine (2010) pada pasien kanker payudara yang kurang dukungan dari lingkungan dapat mengakibatkan pasien kanker payudara menarik diri dan menjauh dalam situasi yang tidak bisa membuatnya bebas dari peran sosial terhadap lingkungan disekitarnya dan tidak bisa memiliki kemampuan untuk semangat bagi lingkungannya.

Berdasarkan hasil penelitian pasien kanker payudara yang memiliki kesejahteraan spiritual yang buruk yaitu tidak pernah memiliki hubungan yang baik dengan lingkungan disekitarnya dan tidak pernah menyatu dengan alam atau lingkunganya. Berdasarkan hasil kuesioner didapatkan bahwa adanya pasien kanker payudara yang mengalami penurunan pada lingkungannya, dimana dilihat pada kuesioner ditemukan (78,3\%) tidak pernah memiliki hubungan yang baik dengan lingkungan disekitarnya, (51,8\%) tidak pernah menyatu dengan alam atau lingkunganya.

Menurut Kurniawati (2015) kesejahteraan spiritual dikaitkan dengan kesejahteraan terhadap Tuhan dan sosial yang dimana melakukan gaya hidup yang agamis sesuai perintah Tuhan, menjalin jaringan sosial spiritual dan yang memiliki jiwa yang optimis. Kesejahteraan spiritual dapat memotivasi seseorang untuk mendapatkan pengalaman religius dan spiritual. Penelitian ini sejalan dengan penelitian Hasnani (2012) individu yang memiliki kemampuan untuk mengidentifikasi kepercayaan spiritualitas positif yang dimilikinya, maka individu tersebut dapat menggunakan kepercayaan tersebut untuk menghadapi situasi lingkungan kesehatan secara positif, jika individu tidak memiliki kemampuan untuk itu maka tidak akan mendapatkan jawaban tentang arti dan tujuan hidupnya.

\section{Hubungan Kesejahteraan Spiritual dengan kualitas hidup pasien kanker payudara}

Berdasarkan hasil penelitian didapatkan bahwa proporsi pasien kanker payudara dengan kualitas hidup yang buruk yang memiliki kesejahteraan spiritual yang buruk $(70,5 \%)$ dibandingkan dengan pasien kanker payudara yang memiliki kesejahteraan spiritual yang baik $(15,4 \%)$. Setelah dilakukan uji statistic Chi-Square didapatkan hasil bahwa $p$ value $0,000(p \leq 0,05)$ artinya terdapat hubungan antara kesejahteraan spiritual dengan kualitas hidup pada pasien kanker payudara di Poli Bedah RSUP Dr. M. Djamil Padang.

Hasil penelitian ini menunjukkan bahwa pasien kanker payudara yang memiliki kualitas hidup buruk lebih banyak ditemukan pada pasien kanker payudara dengan kesejahteraan spiritual yang buruk (70,5\%) dibandingkan dengan pasien kanker payudara dengan kesejahteraan spiritual yang baik $(15,4 \%)$. Hasil dari analisa data yang didapatkan $p$ value $=0.000 \leq p \alpha=0,05$ maka hasilnya ada hubungan bermakna antara kesejahteraan spiritual dengan kualitas hidup pada pasien kanker payudara.

Hasil penelitian ini hampir sama dengan penelitian Kurniawati (2015) menunjukkan bahwa (70,7\%) kesejahteraan spiritual dan kualitas hidup memiliki kaitan yang kuat. Hal ini sejalan dengan penelitian yang dilakukan oleh Vilhena et al (2014) bahwa spiritual memiliki hubungan yang kuat dengan kesejahteraan dan kesehatan mental yang dapat membuat pasien lebih optimis 
dan merasakan kesejahteraan spiritual yang menghasilkan kualitas hidup yang baik.

Berdasarkan hasil penelitian adanya hubungan kesejahteraan spiritual dengan kualitas hidup pada pasien kanker payudara di Poli Bedah RSUP Dr. M.Djamil Padang dapat disimpulkan bahwa pasien kanker payudara merasa memahami dirinya sendiri, merasa memiliki penghormatan terhadap orang lain,merasa memiliki penghormatan terhadap Tuhan, merasa sholat dan berdo'a menambah kekuatan bagi diri pasien kanker payudara, merasa menikmati hidup, merasa memiliki arti dan makna hidup, sehingga lebih dari separoh pasien kanker payudara memiliki kualitas hidup yang baik, hal ini dapat dilihat dari pengisian kuesioner dimana (41\%) pasien kanker payudara tidak harus berbaring di tempat tidur atau dikursi, $(32,5 \%)$ tidak mengalami kesulitan berjalan kaki dalam jarak jauh, $(37,3 \%)$ tidak perlu beristirahat, $(38,6 \%)$ tidak merasa mual.

\section{KESIMPULAN}

Berdasarkan hasil penelitian dapat disimpulkan terdapat hubungan kesejahteraan spiritual dengan kualitas hidup pada pasien kanker payudara di Poli Bedah RSUP Dr. M. Djamil Padang dengan pvalue $=0,000$.

\section{REFERENSI}

Afrimelya, Tika. (2016). Hubungan karakteristik sosio demografi dan depresi dengan kualitas hidup pada wanita dengan kanker payudara di RSUP DR. M. Djamil Padang tahun 2016. Skripsi keperawatan jiwa. Universitas Andalas.

Callys-Tagoe, B. N. L., Senaedza, N. A. H., Arthur, C. A., \& Clegg-Lamptey, J. N. (2017). Anxiety and depression among breast cancer patients in a tertiary hospital in ghana. Postgraduate Medical Journal of Ghana, 26(1). pp 54-58.

Cancer profile in indonesia.2014. Pdf http://www.who.int/cancer/countryprofiles/idn_en.pdf

Endiyono, Herdiaña W. (2016). Hubungan Dukungan Spiritual dan Dukungan Sosial dengan Kualitas Hidup pasien Kanker Payudara di RSUD Prof.Dr. Margono Soekarjo Purwokerto.Jurnal Fakultas
Ilmu Kesehatan Universitas Muhammadiyah Purwokerto.

Fisher, B.B. (2012).Spiritual well being questionnaire: A new instrument for health-related quality of life research. Annals of Family Medicine, 2, 499-503

Idris, M. (2015). Kualitas Hidup Pada Penderita Kanker dengan Status Sosial Ekonomi Rendah. Jurnal Fakultas Psikologi Universitas Muhammadiyah Surakarta.

Josephine, R. (2010). Dampak Penyakit Kanker Terhadap Aspek Psikologis-Sosial dan Spiritual Penderita.

Kanthi, S. (2014). Pengaruh Bimbingan Spiritual Islami Terhadap Kualitas Hidup Pasien Kanker Payudara di RSUD Kabupaten Semarang.

Kurniawati, Henie. (2015). Studi Metanalisis Spiritual Well Being dan Quality of life . Seminar Psikologi dan Kemanusiaan 2015 Psychology Forum Umm, ISBN: 978-979-796-324-8.

Marhamah, S. (2016). Pengaruh Bimbingan Spiritual Islam Terhadap Kualitas Hidup Penderita Kanker Payudara di RSUD Prof. Dr. Margono Soekarjo Purwokerto.

Medical News Today. 2016. Social isolation may lead to poor survival rates in breast cancer patients.

Miranti M., Nuraeni A. (2016). Hubungan Kesejahteraan Spiritual dengan Depresi pada Pasien dengan Penyakit Jantung Koroner (PJK). Jurnal Fakultas Keperawatan Unpad Bandung.

Mulyani NS, Nuryani.(2013). Kanker Payudara dan PMS pada Kehamilan. Yogyakarta: Nuhamedika

Oetami F, dkk. (2014). Analisis Dampak Psikologis Pengobatan Kanker Payudara di RS.Dr. Wahidin Sudirohusodo Kota Makasar. Jurnal Fakultas Kesehatan masyarakat Universitas Hasanudin.

Palmera,C. (2012). Spiritual Well-being. Diakses dari http://casapalmera.com/ spiritual well being

Patricia.,Gonzale. 2014. "spiritual well being and depressive symptoms among cancer survivors". Behavior and community health.Doi: 1-.1007/s00520-014-2207-2. 
Prastiwi, F.T. (2012). Kualitas Hidup Penderita Kanker. Skripsi. Jurusan Psikologi Fakultas IImu Pendidikan. Universitas Negeri Semarang.

Pratiwi, Tita. (2012). Kualitas Hidup Penderita Kanker. Jurnal Developmental and Clinical Psychology Vol 1 No 1 (2012)

Pradana, Putu; Siluh: Surasta. (2012). Hubungan Kualitas hidup dengan Kebutuhan Perawatan Paliatif Pada Pasien Kanker di RSUP Sanglah Denpasar. Jurnal Fakultas kedokteran Universitas Udayana.

Preedy, V.R, and Watson, R.R. (2010).Handbook of Disease Burdens and Quality of Life Measure.Online.

Putri, N. (2016). Hubungan Kesehatan Spiritual dengan Kejadian Depresi Pada Lansia di Panti Sosial Tresna Werdha (PSTW) Sabai Nan Aluih Sicincin Kabupaten Padang Pariaman. Skripsi Keperawatan Gerontik.

Pusat Data dan Informasi Kementerian Kesehatan (Infodatin). (2013). Di akses Situasi Penyakit Kanker. Di akses dariwww.kemkes.go.id

Ratna, W.(2010).Sosiologi dan Antropologi Kesehatan dalam Persepektif Ilmu.Yogyakarta: Pustaka Rihama
Rekamedik RSUP Prof. Dr. M. Djamil Padang. 2017

Robin, Eliane G., Elizabeth Heldt.m Vania N., (2009) Depression and Perception of Quality of life of breast cancer survivors and their male partners.Oncology Nursing Forum . 36, 153-157.

Rondonuwu I, Haroen H, Frans. (2016). Profil Kanker Payudara di RSUP Prof.Dr.R.D.Kandou Manado.Jurnal eClinic Fakultas Kedokteran Universitas Sam Ratulangi Manado

Subagja Prasetya Hamid.(2014). Waspada kanker-kanker ganas pembunuh wanita. Jogjakarta : Flash books.

Srlvastava, V., Ansari, M. A.,... Singh, O. P. (2016). Study of anxiety and depression among breast cancer patient from noth india. Clinical Psychiatry, 2 (1).

Vilhena, E, Pais-Ribeir, J., Silva, I., Pedro, L., Meneses, R. F., Cardoso, $H_{\text {., }}$ and Mendonca, D. (2014).Faktor-Faktor Psikososial sebagai Prediktor Kualitas Hidup PasienKronis di Portugal.(Health and Quality of Life Outcomes, Volume 12 (No.3).Diakses dari http://www.hqlo.com/content/16/12/27 